\title{
NATURAL HISTORY OF THE LIZARD Enyalius brasiliensis (LESSON, 1828) (LEIOSAURIDAE) FROM AN ATLANTIC FOREST OF SOUTHEASTERN BRAZIL
}

\author{
VAN SLUYS, M., FERREIRA, V. M. and ROCHA, C. F. D. \\ Ecologia, Instituto de Biologia Roberto Alcântara Gomes, Universidade do Estado do Rio de Janeiro, Rua São \\ Francisco Xavier, 524, Maracanã, CEP 20550-013, Rio de Janeiro, RJ, Brazil \\ Correspondence to: Monique Van Sluys, Ecologia, Instituto de Biologia Roberto Alcântara Gomes, Universidade do \\ Estado do Rio de Janeiro, Rua São Francisco Xavier, 524, Maracanã, CEP 20550-013, Rio de Janeiro, RJ, Brazil \\ Received December 11, 2002 - Accepted May 22, 2003 - Distributed May 31, 2004
}

\begin{abstract}
Information on the ecology of lizard species from the Brazilian Atlantic Forest is scarce and almost nothing is known about the ecology of lizards of the genus Enyalius. In this study, we provide information about some aspects of the natural history of E. brasiliensis from an area of Atlantic Forest in Ilha Grande, RJ. Enyalius brasiliensis $(\mathrm{N}=15)$ feeds mainly on arthropods. The most frequent food items were insect larvae, orthopterans, and ants; in terms of volume, larvae and termites were the most important food items; ants and termites were the most numerous prey categories. Two females were reproductive (one had 10 and the other, five vitellogenic follicles); the smallest measured $92.4 \mathrm{~mm}$ in SVL. Seven lizards were found on forest leaf litter. The other microhabitats used were vines, fallen logs, branches, and a crevice on a slope.
\end{abstract}

Key words: Enyalius, diet, microhabitat, Atlantic Forest, Rio de Janeiro.

\section{RESUMO}

\section{História natural do lagarto Enyalius brasiliensis (Lesson, 1828) (Leiosauridae) em área de Mata Atlântica do Sudeste do Brasil}

Informações sobre a ecologia de espécies de lagartos da Floresta Atlântica brasileira são raras. Quase nada é conhecido sobre a ecologia de lagartos do gênero Enyalius. Com este estudo fornecemos informações sobre alguns aspectos da história natural de E. brasiliensis de uma área de Mata Atlântica da Ilha Grande, RJ. Os indivíduos de E. brasiliensis $(\mathrm{N}=15)$ se alimentaram principalmente de artrópodos. As presas ingeridas com maior freqüência foram larvas de insetos, ortópteros e formigas; em termos volumétricos, larvas e cupins foram os itens mais importantes; e formigas e cupins foram as presas mais numerosas. Das 10 fêmeas encontradas, duas estavam reprodutivas (uma tinha 10 e a outra, 5 folículos vitelogênicos); a menor delas media $92,4 \mathrm{~mm}$ de tamanho corporal. Sete dos 15 lagartos foram encontrados sobre folhiço no chão da mata. Os outros micro-habitats utilizados foram cipós, troncos caídos, galhos e um barranco de terra dentro de uma fenda de rocha.

Palavras-chave: Enyalius, dieta, micro-habitat, Mata Atlântica, Rio de Janeiro.

Information on the ecology of lizard species from the Brazilian Atlantic Forest is scarce (Sazima \& Haddad, 1992). The study of reptiles in forested habitats is difficult because population densities are generally low, forest species are usually less conspi- cuous than open-habitat forms, vegetation is denser, and large amounts of leaf litter are found on the ground (Duellman, 1987).

Lizards of the leiosaurid genus Enyalius are restricted to forested areas (E. bilineatus is an 
exception) along the Atlantic Rainforest of eastern Brazil and the Brazilian Amazon forest (Jackson, 1978; Ávila-Pires, 1995). Almost nothing is known about the ecology of these lizards, and information available is restricted to accounts of feeding habits and microhabitat use (Vanzolini, 1972; Sazima \& Haddad, 1992; Vitt et al., 1996; Zamprogno et al., 2001; Sousa, 2000). In general, Enyalius lizards are diurnal, insectivorous, and use tree trunks, shrubs, fallen logs, or leaves as perches, they are also commonly found on the ground (Jackson, 1978; Sazima \& Haddad, 1992; Vitt et al., 1996; Zamprogno et al., 2001). A recent study deals with cytogenetical analysis of five species of Enyalius (Bertolotto et al., 2002).

Enyalius brasiliensis (Lesson, 1828) occurs from Itatiaia and Ilha Grande, in Rio de Janeiro State, northward to the southern margin of Rio Doce, in Espírito Santo State (Jackson, 1978). In the Atlantic Forest of Ilha Grande $\left(23^{\circ} 11^{\prime} \mathrm{S}, 44^{\circ} 12^{\prime} \mathrm{W}\right)$, southeastern Brazil, E. brasiliensis is the second most frequently encountered lizard species, after the teiid Tupinambis merianae (Van Sluys \& Rocha, 1999). In this study, we provide information about a few aspects of the natural history of E. brasiliensis, namely diet, microhabitat use, and reproduction.

\section{MATERIAL AND METHODS}

Field work was carried out mainly within two areas. One consisted of a relatively undisturbed forest (ca. $240 \mathrm{~m}$ above sea level) and the other was a 30yr-old regenerated forest (ca. $100 \mathrm{~m}$ above sea level). Lizards were hand-collected whenever encountered during haphazard transects during the morning and afternoon.

Using a vernier caliper, each captured lizard was measured for its snout-vent length (SVL, to the nearest $0.1 \mathrm{~mm}$ ) and weighed (to the nearest $0.1 \mathrm{~g}$ ) using Pesola ${ }^{\circledR}$ spring balances. Diet analysis was based on stomach contents. Lizards were dissected and their stomach contents analyzed under a stereomicroscope. Each prey found was identified as to Order and measured for its maximum length and width, to the nearest $0.1 \mathrm{~mm}$. The volume of each prey type was estimated using a modified version of the formula for a prolate spheroid: volume $=$ $4 / 3 \pi$ (length/2) $\times(\text { width } / 2)^{2}$ (Vitt et al., 1996). An importance index $\left(I_{x}\right)$ was calculated, as in Howard et al. (1999), and represents the relative importance of a prey type in relation to the entire diet. Female reproductive state was based on the presence of vitellogenic follicles and/or oviductal eggs. Clutch size was estimated from counts of vitellogenic follicles or oviductal eggs.

The original position of the microhabitat of each lizard captured was recorded according to five categories: a) on leaf litter on the ground; b) on branches or trunks; c) on fallen logs; d) on vines; and e) in crevices.

\section{RESULTS AND DISCUSSION}

We collected 15 Enyalius brasiliensis (10 females and five males). Females ranged from 48.7 to $100.6 \mathrm{~mm}$ in body size (SVL) and males measured from 68.9 to $85.4 \mathrm{~mm}$. Comparing body size for adults ( $>60.0 \mathrm{~mm})$, there was no significant difference in mean body size for females $(84.8 \pm 13.3 \mathrm{~mm})$ and males $(77.7 \pm 7.1 \mathrm{~mm})(\mathrm{t}$-test: $\mathrm{t}=-1.152 ; \mathrm{df}=9.0$; $\mathrm{p}=0.279)$. Neither did head width differ $(\mathrm{p}=0.411)$ between adults (males: mean $=14.4 \pm 1.2 \mathrm{~mm}$; females: mean $=15.4 \pm 2.3 \mathrm{~mm}$. However, the small sample size prevents further conclusions about sexual size dimorphism for E. brasiliensis.

Of the 10 females collected, two were reproductive. One had 10 vitellogenic follicles and the other had five vitellogenic follicles. Probably, this last female was initiating vitellogenesis. The smallest reproductive female measured $92.4 \mathrm{~mm}$ in SVL. Vanzolini (1972) comments on a female E. catenatus laying two eggs, and Vitt et al. (1996) reports a mean clutch size for $E$. leechii of $12.3 \pm$ 0.7 (range: $10-14 ; \mathrm{N}=6$ ). The two reproductive females were found in November and January, both months of the wet season. The two smallest $E$. brasiliensis collected (body sizes of 48.2 and 48.9 $\mathrm{mm}$ ) were found in January and March, respectively.

The reproductive females of E. leechii analyzed by Vitt et al. (1996) were also collected between December and March, and these authors suspected that reproduction was seasonal. The fact that reproductive females and small-sized lizards were found only during the wet season suggests that E. brasiliensis reproduces seasonally in Ilha Grande also. However, the very limited information available precludes further conclusions about reproduction of Enyalius.

Enyalius brasiliensis at Ilha Grande fed mainly on arthropods (Table 1). One lizard contained no food items in its stomach and was excluded from dietary 
analysis. The most frequent food items were insect larvae, orthopterans, and ants (Table 1). In terms of volume, termites $(34.7 \%)$ and larvae $(16.3 \%)$ were the most important food items, and ants $(43.8 \%)$ and termites $(43.8 \%)$ were the most numerous prey categories ingested by E. brasiliensis (Table 1). Considering the Index of Importance, termites and ants were the dominant prey in the diet of E. brasiliensis. However, this result may be biased due to the large amount of termites eaten by a single individual. Insect larvae were also important prey for $E$. brasiliensis at the study site. There was no significant relationship between lizard body size and mean volume (logtransformed, $\mathrm{r}=0.22 ; \mathrm{F}_{1,9}=0.448 ; \mathrm{p}=0.52$ ) and length of prey $\left(\mathrm{r}=0.56 ; \mathrm{F}_{1,7} \stackrel{\text {, }}{=} 3.239 ; \mathrm{p}=0.115\right)$ ingested.

Little is known about Enyalius feeding habits. Most data indicate they feed on ground insects (Vanzolini, 1972; Sazima \& Haddad, 1992; Vitt et al., 1996; Sousa, 2000; Zamprogno et al., 2001). The diet of $E$. brasiliensis at Ilha Grande was very similar to that of E. leechii in the Amazon (Vitt et al., 1996). The Amazonian E. leechii feeds mainly on relatively soft-bodied arthropods such as termites and caterpillars (Vitt et al., 1996). Enyalius catenatus is a forest dweller which may be found 3 to $5 \mathrm{~m}$ high on tree trunks and also on the ground, where it seems to do a sizable part of its foraging (Vanzolini, 1972). Its diet is mainly composed of arthropods (Vanzolini, 1972). Enyalius iheringii at Serra do Japi, São Paulo State, was observed preying on orthopterans on forest floor leaf litter (Sazima \& Haddad, 1992). Enyalius perditus in the Atlantic Rainforest of Ibitipoca, south of Minas Gerais State, fed mainly on ants, larvae, and isopods (Sousa, 2000). Enyalius bilineatus at a montane Atlantic rainforest area of Espírito Santo State fed on various arthropods, with orthopterans, cockroaches, hymenopterans, and beetles being its most important prey (Zamprogno et al., 2001). The consumption of plant material by E. brasiliensis, although remarkable in terms of volume (35.4\%), was restricted to only three individuals. This suggests that ingestion of plant matter by this lizard may be accidental and may have occurred when lizards were capturing arthropods on the vegetation. The only other reports of plant consumption, also as a consequence of arthropod predation, for Enyalius lizards were made by Sousa (2000) for E. perditus and Zamprogno et al. (2001) for E. bilineatust. Thus, it appears that Enyalius lizards are generalist predators which feed on ground arthropods.

TABLE 1

Diet composition of the lizard Enyalius brasiliensis $(\mathrm{N}=14)$ at Ilha Grande, Rio de Janeiro. Freq. (\%) = number (and percentage) of stomachs containing that prey item; Vol. $(\%)=$ volume, in $\mathrm{mm}^{3}$, and volumetric percentage of each prey type; $\mathrm{N}(\%)=$ total number (and numeric percentage) of prey items in each prey category; and $I_{x}=$ importance index.

\begin{tabular}{|c|c|c|c|c|}
\hline Item & Freq. (\%) & Vol. (\%) & $\mathbf{N}(\%)$ & $I_{x}$ \\
\hline Homoptera nymph & $1(7.14)$ & $321.53(1.91)$ & $1(0.57)$ & 0.0321 \\
\hline Orthoptera & $4(28.57)$ & 571.27 (3.39) & $4(2.25)$ & 0.1140 \\
\hline Coleoptera & $1(7.14)$ & $69.59(0.41)$ & $2(1.14)$ & 0.0290 \\
\hline Larvae & $5(35.71)$ & $2746.99(16.29)$ & $11(6.25)$ & 0.1942 \\
\hline $\begin{array}{l}\text { Hymenoptera } \\
\text { Formicidae }\end{array}$ & $4(28.57)$ & $371.84(2.21)$ & $77(43.75)$ & 0.2484 \\
\hline Isoptera & $1(7.14)$ & $5851.07(34.70)$ & $77(43.75)$ & 0.2853 \\
\hline Diplopoda & $2(14.29)$ & $244.13(1.45)$ & $2(1.14)$ & 0.0563 \\
\hline Mollusca gastropoda & $2(14.29)$ & $198.67(1.18)$ & $2(1.14)$ & 0.0554 \\
\hline Scales & $1(7.14)$ & - & - & - \\
\hline Arthropod remains & $7(50.00)$ & $5965.88(3.10)$ & - & - \\
\hline Plant matter & $3(21.43)$ & $522.25(35.38)$ & - & - \\
\hline Total & - & $16,863.22$ & 176 & - \\
\hline
\end{tabular}


Most Enyalius brasiliensis (14/15) were found during morning transects and only one was found at 4:30 pm. On this subject, information about Enyalius activity is also scant. Most reports state that these lizards are diurnal, not specifying whether they are active all day long or only during parts of the day (Vanzolini, 1972; Jackson, 1978; Sazima \& Haddad, 1992). At this point we cannot confidently define the activity pattern of $E$. brasiliensis but evidence points to more activity, at least in the understory, during the morning. Seven of the fifteen lizards $(46.7 \%)$ were found on leaf litter. The other microhabitats used were vines $(6.7 \%)$, fallen logs $(6.7 \%)$, branches (13.3\%), and one pair (13.3\%) was found inside a crevice on a slope bordering a trail. Mean height above ground was $76.0+30.5 \mathrm{~cm}(\mathrm{~N}=5)$ and, for two individuals, mean perch diameter was $16.4+5.2 \mathrm{~mm}$. These results are similar to those previously reported for E. catenatus (Vanzolini, 1972) and E. leechii (Vitt et al., 1996).

Enyalius brasiliensis at Ilha Grande is a diurnal, carnivorous lizard, which feeds mainly on ants, termites, and insect larvae. However, more data are needed to provide information about the ecology of these lizards.

Acknowledgments - This study is part of the BIOTA/FAPESP Project and was partially supported with a grant from this Agency (process No. 99/08291-5) and is also a portion of the results of the Programa de Ecologia, Conservação e Manejo de Ecossistemas do Sudeste Brasileiro and of the Southeastern Brazilian Vertebrate Ecology Project (Vertebrate Ecology Laboratory), both of the Setor de Ecologia, Instituto de Biologia, Universidade do Estado do Rio de Janeiro. This study was also partially supported by grants from the Conselho Nacional do Desenvolvimento Científico e Tecnológico (CNPq) to MVS (\# 302405/ 02-0), to CFDR (\# 307653/03-0 and 477981/03-0), and from FAPERJ (\# E-26/172.383/2000, to MVS). VMF has been granted by an undergraduate fellowship from UERJ (Pibic/UERJ). We thank Centro de Estudos Ambientais e Desenvolvimento Sustentável (CEADS/UERJ) at Ilha Grande for logistic support. We are grateful to many of our students who provided field assistance throughout the Project. D. Vribradic and D.M. Peccinini-Seale kindly revised the manuscript and offered helpful suggestions.

\section{REFERENCES}

ÁVILA-PIRES, T. C. S., 1995, Lizards of Brazilian Amazonia (Reptilia: Squamata). Zool. Verh. (Leiden), 299: 1-706.

BERTOLOTTO, C. E. V., PELLEGRINO, K. C., RODRIGUES, M. T. \& YONENAGA-YASSUDA, Y., 2002, Comparative cytogenetics and supernumerary chromosomes in the Brazilian lizard genus Enyalius (Squamata, Polychrotidae). Hereditas, 136: 51-57.

DUELLMAN, W. E., 1987, Lizards in an Amazonian rainforest community: Resource utilization and abundance. Nat. Geogr. Res., 3: 489-500.

HOWARD, A. K., FORESTER, J. D., RUDER, J. M., PAMERLEE, JR., J. S. \& POWELL, R., 1999, Natural history of a terrestrial Hispaniolan Anole: Anolis barbouri. J. Herpetol., 33: 702-706.

JACKSON, J. F., 1978, Differentiation in the genera Enyalius and Strobilurus (Iguanidae): Implications for Pleistocene climatic changes in eastern Brazil. Arq. Zool., S. Paulo, 30: $1-79$.

SAZIMA, I. \& HADDAD, C. F. B., 1992, Répteis. In: L. P. C. Morellato (org.), História Natural da Serra do Japi. Campinas, São Paulo, pp. 212-236.

SOUSA, B. M., 2000, Aspectos ecológicos, comportamentais e morfológicos associados à alimentação de Enyalius perditus Jackson, 1978 (Sauria: Polychrotidae). Unpubl. MSc. Dissertation, UFJF, Juiz de Fora, 168p.

VAN SLUYS, M. \& ROCHA, C. F. D., 1999, Tupinambis merianae (Common Tegu): Activity. Herp. Rev., 30: 42-43.

VANZOLINI, P. E., 1972, Miscellaneous notes on the ecology of some Brazilian lizards (Sauria). Papéis Avulsos de Zoologia, S. Paulo, 26: 83-115.

VITT, L. J., ÁVILA-PIRES, T. C. \& ZANI, P., 1996, Observations on the ecology of the rare amazonian lizard, Enyalius leechii (Polychrotidae). Herpetological Natural History, 4: 77-82.

ZAMPROGNO, C., ZAMPROGNO, M. G. F. \& TEIXEIRA, R. L., 2001, Evidence of terrestrial feeding in the arboreal lizard Enyalius bilineatus (Sauria, Polychrotidae) of SouthEastern Brazil. Rev. Bras. Biol., 61: 91-94. 